Supporting Information for

\title{
ABSOLUTE QUANTIFICATION OF PHOTO/ELECTRO- LUMINESCENCE IMAGING FOR SOLAR CELLS: DEFINITION AND APPLICATION TO ORGANIC AND PEROVSKITE DEVICES
}

EMILIE PLANES ${ }^{1, *}$, MANON SPALLA ${ }^{1,2}$, SACHA JUILLARD ${ }^{1,2}$, LARA PERRIN $^{1}$, LIONEL FLANDIN ${ }^{1}$

${ }^{1}$ Univ. Grenoble Alpes, Univ. Savoie Mont Blanc, CNRS, Grenoble INP, LEPMI, 38000

Grenoble, France

${ }^{2}$ Univ. Grenoble Alpes, CEA, LITEN, INES, 73375 Le Bourget du Lac, France

*To whom correspondence should be addressed.

Email: emilie.planes@univ-smb.fr

\section{Table of contents}

Experimental: $J(V)$ measurement.

Figure S1. Influence of focal length on mean gray level for organic (OPV) and perovskite (PK) solar cells tested in PL imaging (OPV cell: T=600 ms; Aperture=16; PK Cell: T=1000ms; Aperture $=16$ ).

Figure S2. J(V) measurements (under 1.5AM light) of a representative organic solar cell before and after encapsulation.

Figure S3. J(V) characteristics (under 1.5AM light) of a representative perovskite solar cell ........4

Table S1. PV parameters of organic (before and after encapsulation) and perovskite solar cells ...5 (averages and uncertainties obtained on 10 solar cells for each type).

Figure S4. PL spectra of half-cells and full devices for both a) organic (Worth mentioning that halfcell and encapsulated solar cell presented spectral measurements were not performed using the same experimental tool, and thus intensities should not be directly compared.) and b) perovskite architectures

Figure S5. Comparison of PV characteristics before and after EL imaging (for the OPV cell presented in figure 8). J(V) measurements of organic solar cell under 1.5AM light.

Figure S6. Comparison of PV characteristics before and after EL imaging (for the PK cell presented in figure 8). $\mathrm{J}(\mathrm{V})$ measurements of perovskite solar cell under 1.5AM light............................7

Table S2. PV parameters of solar cells characterized in figure 8 , before and after EL imaging .....8 


\section{Experimental: $J(V)$ measurement.}

The fill factor $(\mathrm{FF})$, short circuit current $\left(\mathrm{J}_{\mathrm{sc}}\right)$, open circuit voltage $\left(\mathrm{V}_{\mathrm{oc}}\right)$, power conversion efficiency $(\mathrm{PCE})$, as well as series $\left(\mathrm{R}_{\mathrm{s}}\right)$ resistances were obtained from current-voltage $\mathrm{I}(\mathrm{V})$ measurements. The I(V) characteristics of the devices were recorded via a computer controlled Keithley Source-Measure Unit (SMU 2400). These measurements were carried out under nitrogen atmosphere (inside a glove box) using a AM 1.5, $100 \mathrm{~mW} . \mathrm{cm}^{-2}$ illumination, obtained by an Oriel SP94043A (Xe Lamp) solar simulator. A monocrystalline silicon solar cell, calibrated at the Fraunhofer Institut für Solare Energie Systeme (Freiburg, Germany), was used as the reference cell to adjust the illumination intensity to $100 \mathrm{~mW} / \mathrm{cm}^{2}$. 


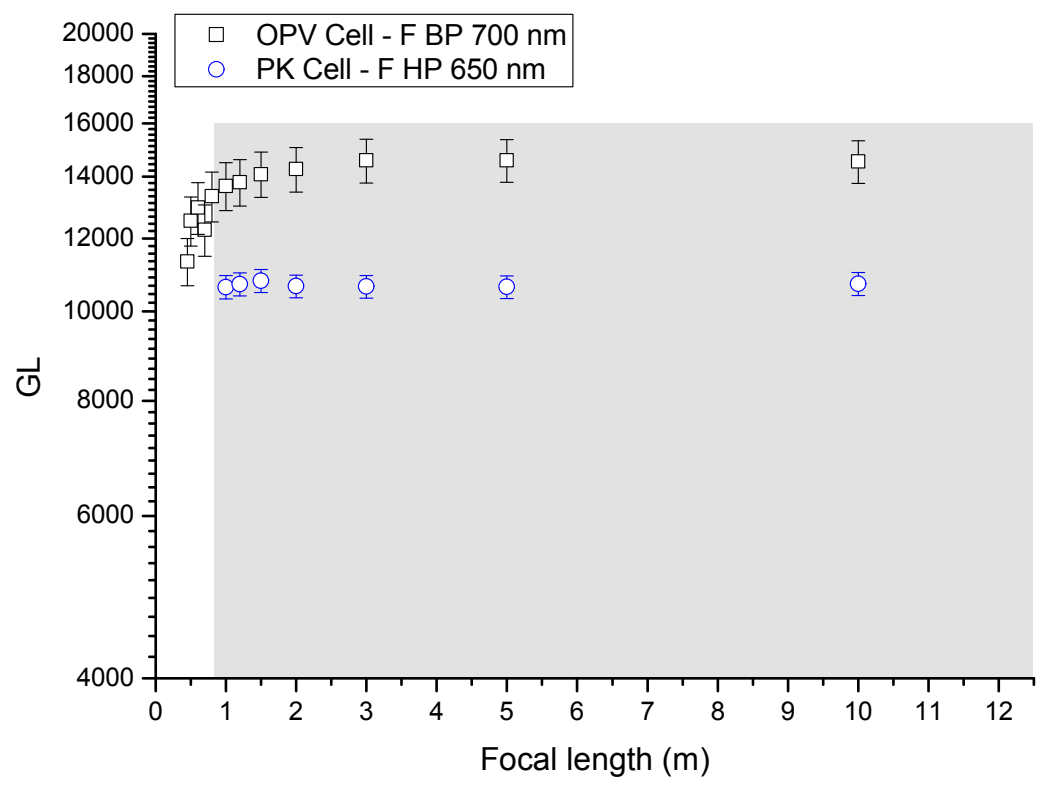

Figure S1. Influence of focal length on mean gray level for organic (OPV) and perovskite (PK) solar cells tested in PL imaging (OPV cell: T=600 ms; Aperture=16; PK Cell: T=1000ms; Aperture = 16). 


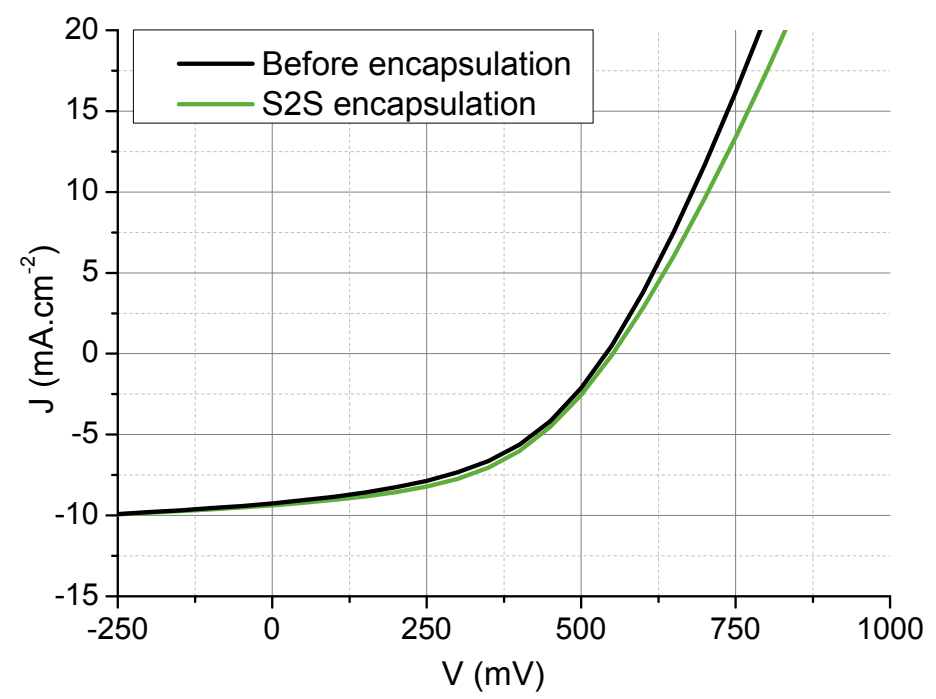

Figure S2. J(V) measurements (under 1.5AM light) of a representative organic solar cell before and after encapsulation

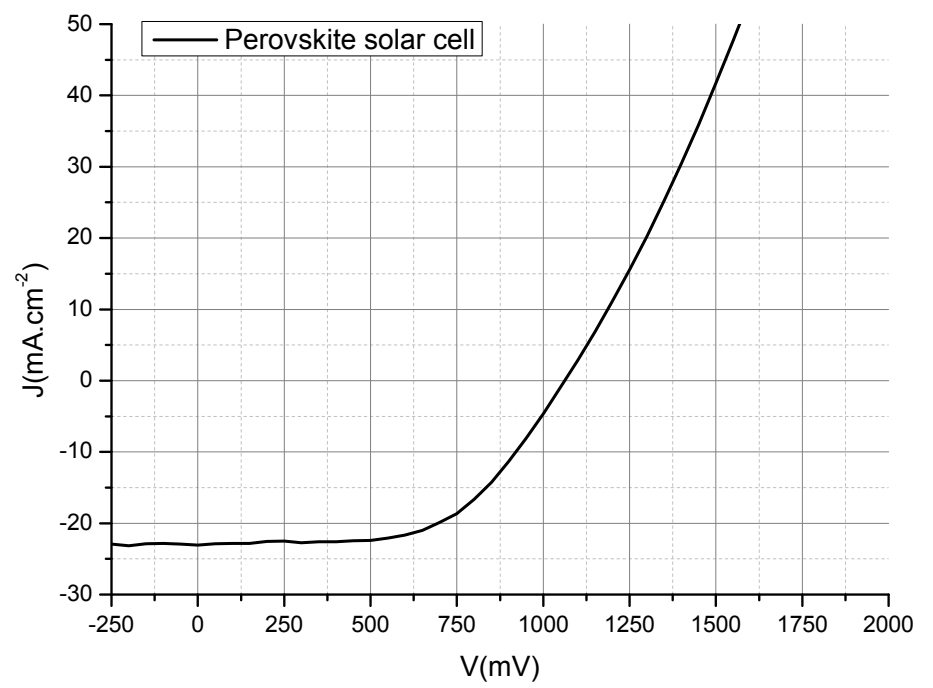

Figure S3. J(V) characteristics (under 1.5AM light) of a representative perovskite solar cell 


\begin{tabular}{|c|c|c|c|c|c|}
\hline & PCE & FF & Voc & Jsc & Rs \\
& $(\%)$ & $(\%)$ & $(\mathrm{mV})$ & $(\mathrm{mA})$ & $\left(\mathrm{Ohm}^{2} \mathrm{~cm}^{2}\right)$ \\
\hline Organic Solar Cell & $2.3 \pm 0.4$ & $42 \pm 5$ & $503 \pm 18$ & $11.5 \pm 1.5$ & $29 \pm 15$ \\
\hline Oefore encapsulation & & & & & \\
\hline After S2S encapsulation & $2.4 \pm 0.4$ & $44 \pm 3$ & $502 \pm 26$ & $10.4 \pm 1.4$ & $18.5 \pm 5$ \\
\hline Perovskite Solar Cell & $13.8 \pm 1.0$ & $57 \pm 3$ & $1057 \pm 12$ & $23.0 \pm 0.5$ & $11.7 \pm 3$ \\
\hline
\end{tabular}

Table S1. PV parameters of organic (before and after encapsulation) and perovskite solar cells (averages and uncertainties obtained on 10 solar cells for each type). 

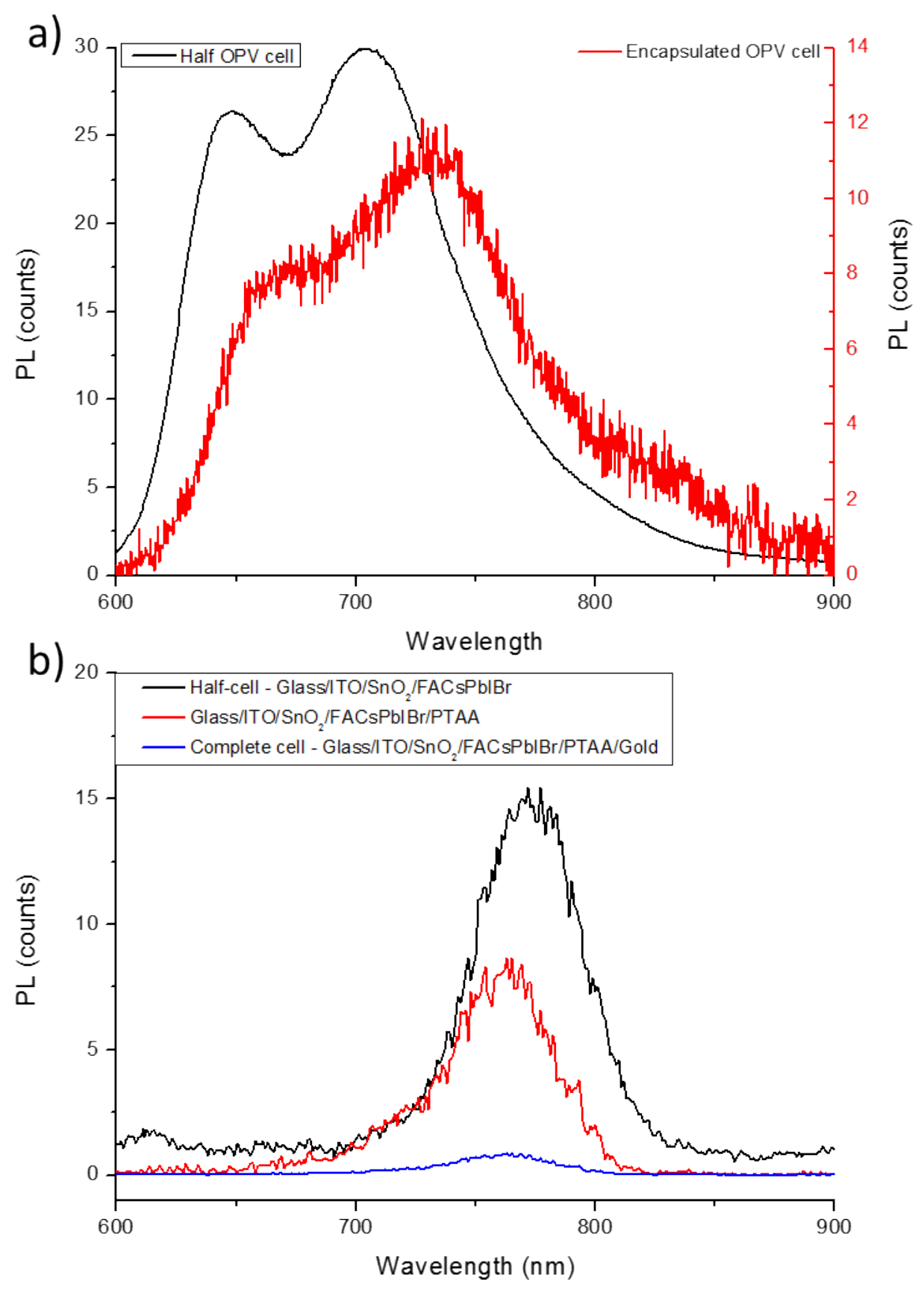

Figure S4. PL spectra of half-cells and full devices for both a) organic (Worth mentioning that half-cell and encapsulated solar cell presented spectral measurements were not performed using the same experimental tool, and thus intensities should not be directly compared.) and b) perovskite architectures 


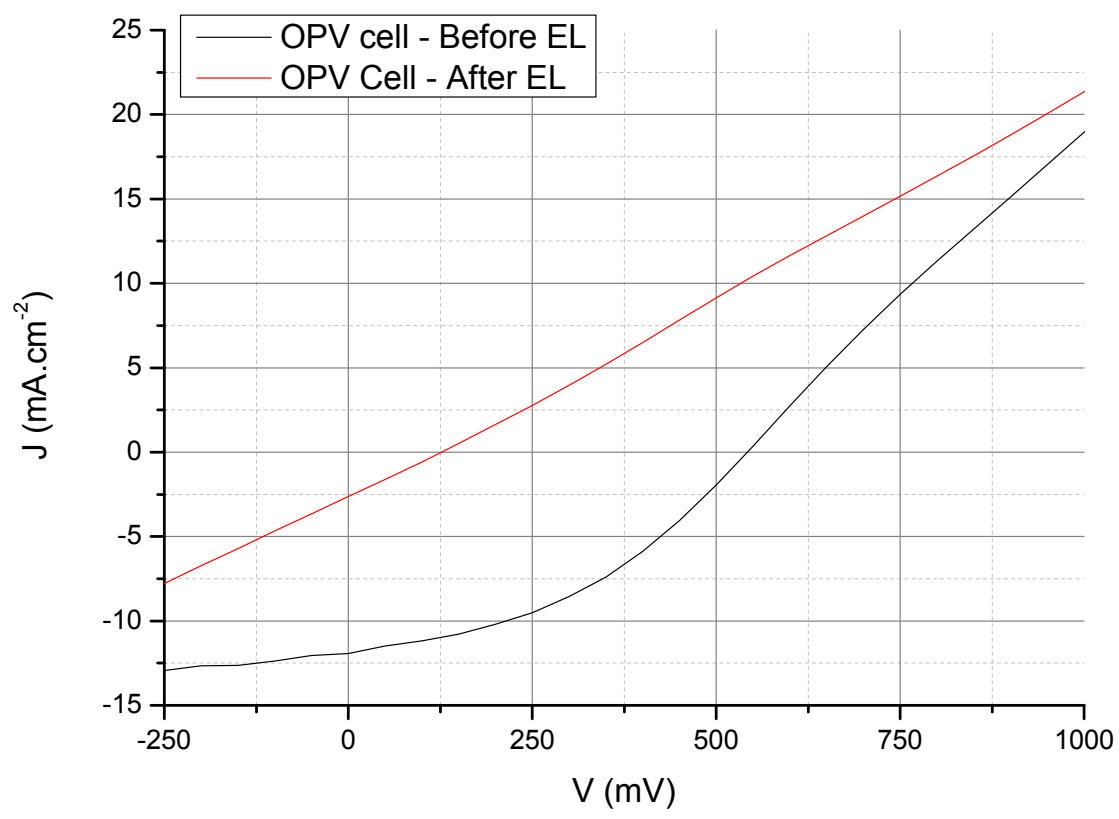

Figure S5. Comparison of PV characteristics before and after EL imaging (for the OPV cell presented in figure 8). $\mathrm{J}(\mathrm{V})$ measurements of organic solar cell under 1.5AM light.

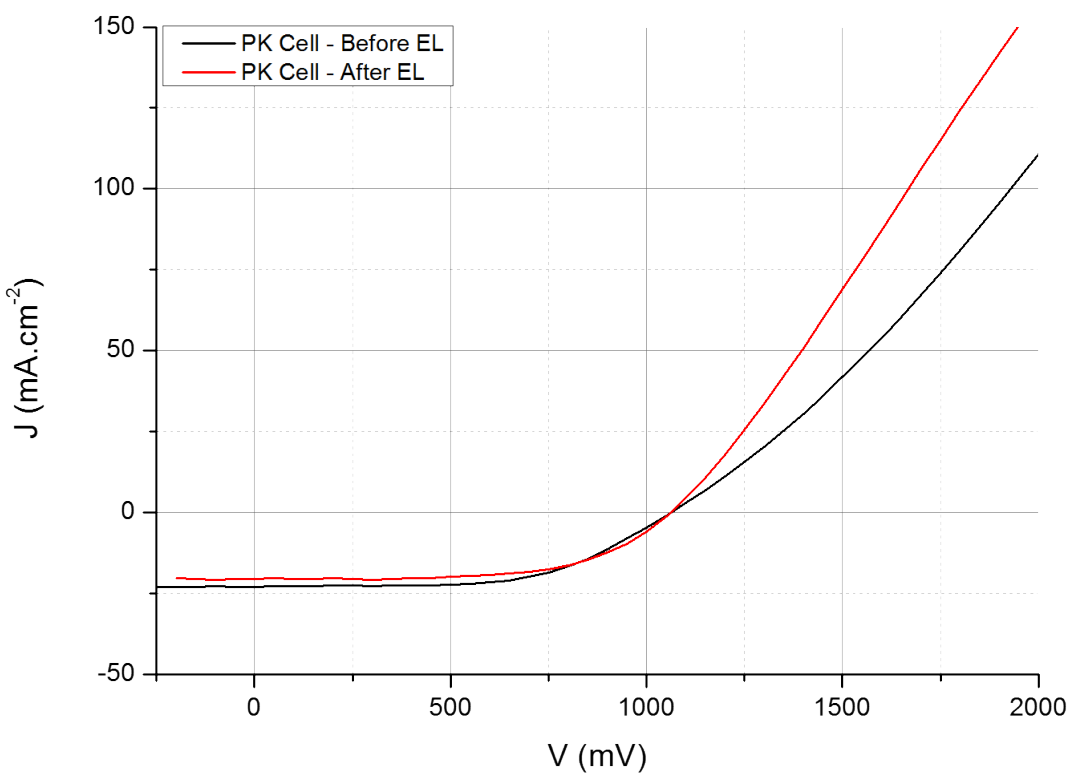

Figure S6. Comparison of PV characteristics before and after EL imaging (for the PK cell presented in figure 8). $\mathrm{J}(\mathrm{V})$ measurements of perovskite solar cell under 1.5AM light. 


\begin{tabular}{|c|c|c|c|c|c|c|}
\hline & & $\begin{array}{c}\text { PCE } \\
(\%)\end{array}$ & $\begin{array}{c}\text { FF } \\
(\%)\end{array}$ & $\begin{array}{c}\text { Voc } \\
(\mathrm{mV})\end{array}$ & $\begin{array}{c}\text { Jsc } \\
(\mathrm{mA})\end{array}$ & $\begin{array}{c}\text { Rs } \\
\left(\mathrm{Ohm}^{2} \mathrm{~cm}^{2}\right)\end{array}$ \\
\hline \multirow{3}{*}{ Organic Solar Cell } & Before EL & 2.6 & 41 & 543 & 11.8 & 25 \\
\cline { 2 - 7 } & After EL & --- & --- & --- & --- & --- \\
\hline \multirow{3}{*}{ Perovskite Solar Cell } & Before EL & 14.1 & 58 & 1067 & 22.7 & 8.2 \\
\cline { 2 - 7 } & After EL & 13.5 & 60 & 1060 & 20.1 & 5.8 \\
\hline
\end{tabular}

Table S2. PV parameters of solar cells characterized in figure 8, before and after EL imaging 